\title{
SEMIOTIKA KARIKATUR PANDEMI COVID-19 MELALUI MEDIA DARING (ON LINE) DI PERANCIS
}

\author{
Mardi Adi Armin ${ }^{1}$, Nafiatul Amalia ${ }^{2}$ \\ Universitas Hasanuddin 1,2 \\ mardi.adi@unhas.ac.id ${ }^{1}$, nafiatul.lia96@gmail.com ${ }^{2}$
}

\begin{abstract}
This study investigates the caricature representations contained in online media regarding the French government's response to the Civod-19 Pandemic. Also examined the response of citizens to government policies, including religious and other professional society. This research was conducted to try to examine aspects of Corona pandemic reporting through online media, because this issue has become a worldwide concern. Pandemic has caused many victims The response of the community is directly reflected in the caricature. by using the semiotic approach, we will get the meanings of the caricatures under study. Caricature is the data in this study. Caricature as data is divided into four: caricature of the government version, caricature of the community version, caricature of the professional version and caricature which is a critique of the Chinese governmentThe scientific method used is semiotics as a theory that can interpret the explicit and implicit meaning of an image. The results of the study found that the French Government remained criticized despite trying to handle the pandemic to the maximum. Also depicted a sense of optimism and pessimism of citizens facing disaster. Also found criticism of the Chinese Government that is not open to investigations of the origin of the virus.
\end{abstract}

Keywords: Caricature, Government, Optimism, Pessimism, China

\section{PENDAHULUAN}

Tanpa dapat diprediksi sebelumnya warga dunia memasuki tahap yang begitu sulit pada permulaan tahun 2020 ini. Semua negara di lima benua dibuat sibuk dengan respon yang bermacam-macam, Beberapa negara dengan cerdas, sukses menangani bencana kesehatan tersebut. Sebaliknya negara yang lainnya masih menderita dan belum berhasil keluar dari kesulitan tersebut, bahkan satu dua negara hampir-hampir tergoyahkan sendi-sendi pemerintahannya.

Sejak merebak akhir tahun 2019 lalu di kota Wuhan, Provensi Hubei, Cina, Corona virus telah melanda sebagian besar negara-negara di dunia mencakup lima benua, dengan menimbulkan kematian yang besar. Beberapa asumsi mengenai asal virus dikemukakan oleh para ahli misalnya dikatakan virus berasal dari kelelawar, yaitu binatang yang diperjualbelikan di pasar dalam kota Wuhan, provinsi Hubei.

Le virus peut "Le virus peut avoir muté vers sa forme finale adaptée pour les humains il y a des mois, mais est resté à l'intérieur d'une chauve-souris ou d'un autre animal ou même d'un homme pendant plusieurs mois sans infecter d'autres personnes. Ensuite il a commencé à infecter les humains et à se propager entre le 13 septembre et le 7 décembre», a déclaré jeudi 16 avril un généticien de l'Université de Cambridge, Peter Forster, cité par le South China Morning Post. (Sputnik France. 17 4-2020).

Ada pula pendapat yang mengatakan bahwa virus bermula dari pegawai laboratorium di Wuhan yang terinfeksi oleh penelitiannya. Hingga tuduhan yang bersifat spionase bahwa virus sebagai senjata biologis yang dibawah oleh tentara Amerika yang datang ke Cina beberapa bulan sebelumnya. Tuduhan ini disampaikan sendiri oleh Pemerintah Cina.

Sementara itu pemenang nobel bidang kesehatan pada tahun 2008, yaitu penemu virus penyebab HIV, Prof Luc Montaignier menyatakan bahwa Corona virus tidak muncul secara alami melalui penularan 
hewan kepada manusia. Menurut dia, virus ini dibuat dari ADN VIH di laboratorium Wuhan. Luc Montagnier, prix Nobel de médecine, a affirmé que le coronavirus n'était pas apparu de manière naturelle via une transmission animal-humain. Selon lui, le virus a été créé à partir de l'ADN de $V I H$ dans un laboratoire de Wuhan spécialisé dans ce domaine. Sputnik.France, 17.4. 2020.

Hal yang perlu dikhawatirkan lagi, Virus Corona sampai sekarang belum ditemukan vaksin atau obatnya. Para ahli di seluruh dunia berupaya keras untuk mendapatkan obat. Mulai dari pemakaian cloroquine, hydroxycholoquine hingga hipotesis jahe merah dan sinar matahari di Indonesia, dapat menjadi obat. Beberapa situasi kontras ditemukan antara hasil diagnosis gejala penyakit paru-paru berdasarkan foto radiologis dan scan dengan fakta infeksi yang terdapat pada pasien, sebab tidak tampak pada scan. Seperti dikemukakan oleh Vladimir Nikiforov, ahli penyakit infeksi (agence federale medicobiologique (fmba) Rusia (fr.sputnicnews.com 20.4.2020, seperti dikutip di bawah ini:

Plusieurs incohérences entre l'état de santé d'un infecte au covid-19 et les résultas des analyses obtenus par scanner ou radiographie.....la phénomonie peut ne pas être visible sur les radios, les scanner montrant parfois, pour sa part, un état grave de poumons alors que le malade se porte bien.....certaines singularité du covid -19 qui ne renrent pas dans le cadre du deroulement habituel des infections virales 17:26 20.04.2020(mis à jour 17:28 20.04.2020).

Dalam kelanjutannya, Pandemi Covid-19 tidak dapat lagi dinilai sebagai persoalan bidang kesehatan atau virologi semata, melainkan telah berubah menjadi persoalan multidimensional, meliputi Ekososbudhum bahkan politik Nasional dan Internasional suatu negara. Pandemi Covid-19 mempertanyakan hakekat dasar manusia dan kemanusian dalam kehidupan. Covid-19 segera menjadi ujian bagi elit politik semua negara dalam membuktikan dan memperteguh komitmen serta serta pengabdian mereka terhadap bangsa dan negara masing-masing. Sementara bagi warga negara, ini merupakan pembuktian terhadap kesadaran dan partisipasi kolektif untuk taat dan patuh pada peraturan yang dicanangkan oleh elit negara dan pemerintahan.

Beberapa sikap moral yang diharapkan terbangun baik dari sisi pemerintah maupun sisi warga negara antara lain: kesetiakawanan sosial dan keteladanan.

\section{a. Kesetiakawanan Sosial}

Di samping manusia sebagai makhluk rasional yang memiliki akal pikiran dan dengan modal akal pikiran tersebut, manusia membangun kebudayaan dan peradaban, manusia juga adalah makhluk sosial yang berkelompok satu sama lain dalam suatu komunitas yang disebut masyarakat. Kesetikawanan sosial adalah sikap hidup yang dimiliki seseorang untuk selalu peduli terhadap penderitaan orang lain. Merasa senasib sepenanggungan baik dalam suka maupun dalam duka. Sikap hidup tersebut seyogyanya melampaui identitas etnis dan kelompok, sebab dasarnya adalah kemanusiaan. Persamaan kemanusiaan yang jauh melampaui perbedaan agama, dan bahasa. Tidak ada tempat bagi prinsip liyan (the outher). Liyan (yang lain) dalam filsafat fenomenologi digunakan dalam mengidentifikasi dan membedakan diri dengan yang lain dalam pengakuan mereka untuk menjadi eksistensi. Oleh karena itu, Yang Lain berbeda dan berlawanan dengan diri. Meskipun liyan terpisah dari diri, liyan merupakan realitas ada yang juga mengukuhkan keberadaan diri. Pengalaman ada bersama yang lain ini membawa konsekuensi bahwa diri juga ada bagi yang lain.

Hal ini jauh pula dari pandangan filsafat eksistensialis Jean Paul Sartre bahwa liyan adalah "neraka bagi saya" (l'autre est l'enfers), di mana liyan tersebut membatasi kebebasan-kebebasan eksistensial saya. Sama saja, ini jauh pula dari pandangan teman hidup Sartre, Simone de Beauvoir yang menyatakan bahwa manusia yang memiliki kebebasan adalah manusia yang berfungsi sebagai subjek dan 
dan sebaliknya manusia yang tidak bebas adalah objek. Akibatnya, dalam kehidupan ini yang harus dilakukan adalah berlomba untuk meng-objekan.

Dalam relasi gender antara laki-laki dan perempuan Simone de Beauvoir menempatkan perempuan sebagai liyan, karena menurutnya perempuan dikonstruksi oleh budaya melalui penciptaan mitos tentang perempuan yang irasional, kompleks, sulit dimengerti, dan tercipta untuk menjadi pelengkap lakilaki. Perempuan menerima ke-liyan--an mereka sebagai misteri feminin, yang diturunkan dari generasi ke generasi melalui sosialisasi perempuan. Perempuan didefinisikan dengan referensi kepada lakilaki dan bukan referensi kepada dirinya sendiri, dengan demikian perempuan adalah insidental semata, bukan esensial. Laki-laki adalah subjek, sedangkan perempuan adalah orang lain atau liyan.

Semua manusia dilahirkan dalam keadaan sama, derajat yang sama, setara dan egaliter. Oleh karena itu, tidak ada alasan untuk membedakan manusia atas manusia lain di dunia baik dalam hak, kewajiban maupun kemuliaan dan harga diri. Jika pada kenyataannya perbedaanperbedaan itu ada dan dipraktekkan, maka tentu itu berkaitan dengan politik sektarian yang bersifat militan dan diskriminatif yang dilakukan oleh orang kaya kepada orang miskin, yang memiliki status sosial kepada yang tidak memiliki status sosial bahkan dilakukan oleh penguasa zalim dalam paradigma yang sering disebut sebagai paradigma de l'homme par l'homme.

Sikap saling membantu dan saling pengertian (mutual understanding) adalah perkara penting dalam kehidupan di tengah bencana Covid-19. Saling pengertian yang berangkat dari rasa tanggung jawab etis dan moral untuk menyebarkan budaya hidup bersama dalam semangat perdamaian. Semangat tersebut hendaknya berbarengan wujudnya dengan tindakan untuk merangkul mereka yang menderita, terpinggirkam dan tidak mendapat hakhanya. Khusus untuk negara-negara Barat mereka yang dimaksud terutama adalah kaum imigran dan pengungi dan negaranegara korban perang di Eropa Timur,
Timur Tengah dan benua hitam, Afrika. Sehingga, berbuat baik kepada mereka adalah bagian dari persaudaraan kemanusian yang selanjutnya akan mewujudkan perdamain hidup bersama (koeksistensi). Hal ini bahkan sejalan dengan pandangan HAM yang menganjurkan kewajiban untuk membangun dan menyebarkan nilai kebaikan kasih sayang dan persaudaraan, di mana seluruh jiwa manusia dilahirkan dalam kedaan suci dan dilarang untuk dizalimi.

Sikap-sikap seperti ini niscaya akan jauh dari anti diskriminasi, dan sebaliknya yang terjadi adalah mengulurkan pertolongan sebagai kewajiban sesama manusia, membangun solidaritas, dan tidak ada yang terbuang (eksil), tanpa pilih kasih. Yang ada hidup bersama secara damai. Persaudaraan kemanusiaan yang menyatukan politik sektarian, militansi, diskriminasi, dan ekploitasi sistem yang mengambil keuntungan, orientasi ideologis serta fanatisme yang sempit. Kemerdekaan kepada seluruh manusia, keadilan, kasih sayang sebagai pondasi kebaikan dan kemaslahatan, memiliki kehendak baik (goodwiill).

b. Keteladanan adalah penting dalam masamasa krisis ini, bahwa elit dan pemegang kekuasaaan harus pertama-tama memberikan teladan. Mereka yang pertama kali mengambil kebijakan dan contoh bagi rakyat, tidak berhenti pada jargon-jargon politik yang demagogik semata. Pada penjelasan mengenai keteladanan tersebut, terdapat istilah umum yang dapat dirujuk dalam istilah Ing Ngarsa Sung Tulada bahwa elit dan pemimpin harus memberi teladan atau contoh tindakan yang nyata dan benar.

\section{METODE}

Disiplin ilmu semiotika adalah ilmu yang tidak lepas membahas serta menganalisis mengenai tanda yang melatih kita agar dapat berfikir serta bernalar mengenai tanda-tanda yang ada di sekeliling kita. Tanda secara alamiah merupakan bentuk komunikasi manusia non verbal, tanda akan bekerja jika dihubungkan dengan elemen yang berada 
pada lingkungannya. Suatu ilmu yang mempelajari makna dari suatu tanda atau lambang merujuk pada bidang studi semiotika. Istilah semiotika berasal dari bahasa Yunani yaitu semeion yang berarti 'tanda' atau seme yang berarti penafsir tanda, atau dalam sebutan bahasa Inggris "semiotics". Jadi, semiotika adalah ilmu yang mengkaji tentang tanda. Menurut Zoest (1993) semiotika adalah cabang ilmu yang berurusan dengan pengkajian tanda dan segala sesuatu yang berhubungan dengan tanda, seperti tanda dan proses yang berlaku bagi pengguna tanda. Tanda merupakan sebuah unsur yang sangat penting dalam berperilaku dan berkomunikasi karena bisa memunculkan berbagai makna agar pesan dapat dimengerti (Adilia, 2019).

Semiotika secara garis besar memiliki dua tokoh, yang dikenal dengan bapak linguistik yaitu Ferdinand de Saussure dan seorang ahli filsafat dan logika yaitu Charles Sander Peirce. Semiotika merupakan disiplin ilmu yang mengkaji tanda, proses menanda dan proses menandai. Semiotika berasal dari kata Yunani semeion yang berarti "tanda" dalam bahasa Inggris disebut Semiotics. Semiotika berarti ilmu uang mempelajari tentang tanda, semiotika cabang ilmu yang mengkaji tanda dan semua yang bersangkutan dengan tanda, seperti halnya tanda dan proses yang berlaku pada penggunaan tanda. (Zoest, 1993). Semiotika memiliki istilah lain yaitu semiology, semiotika dan semiology memiliki pengertian yang sama. Penggunaan pada kedua istilah tersebut merujuk pada pemikirannya masingmasing. Peirce menyebutnya sebagai semiotika beda halnya dengan Saussure yang memakai istilah Semiologi. Saussure mendefinisikan semiotika sebagai ilmu yang meneliti tanda sebagai bagian dari kehidupan social. Saussure memiliki prinsip bahwa semiotika akan mengingatkan nya pada aturan main (rule) dank ode social (social code) dan berlaku pada masyarakat sehingga tanda dapat dipahami maknanya secara kolektif. (Saussure 1990).

Saussure menjelaskan bahwa semiotika merupakan ilmu yang mempelajari tentang suatu tanda dan merupakan simbol yang berupa kata, maupun gambar. Tanda merupakan sesuatu yang dapat dipakai untuk sesuatu yang lain, tanda-tanda tersebut mengemban arti (signifiant) yang mana pembaca akan menghubungkan tanda dengan apa yang ditandakannya (signife) berdasarkan sistem bahasa yang bersangkutan. (Hoed, 2011). Sedangkan Peirce mengemukakan semiotika bersinonim dengan logika, manusia hanya berfikir dalam tanda, baginya semiotika bersinonim dengan logika. Secara harfiah pierce mengatakan "kita hanya berfikir dalam tanda" Peirce melihat tanda sebagai unsur dalam komunikasi. Tanda hanya berarti tanda apabila ia berfungsi sebagai tanda (Zoest 1993).

Menurut Saussure hubungan antara penanda dan petanda bersifat arbitrer (bebas) baik secara kebetulan ataupun dengan ditetapkan. Sedangkan menurut peirce tanda merupakan sesuatu yang mewakili sesuatu, sesuatu yang diwakili adalah pengalaman manusia baik fisik atau mental. Tanda mempunyai relasi triadik langsung pada interpretan dan objeknya. Pemaknaan tanda terjadi pada sebuah proses yang disebut dengan dimensi semiosis, tanda yang ditangkap oleh penerima tanda adalah representamen (penanda) yang berdasarkan pengetahuan yang merujuk pada objek (Hoed 2011).

Suatu analisis esensi tanda mengarah pada pembuktian bahwa setiap tanda ditentukan oleh objeknya. Pertama, ketika saya menyebut tanda suatu ikon, maka suatu tanda akan mengikuti sifat objeknya. Kedua, ketika saya menyebut tanda suatu indeks, kenyataan dan keberadaan tanda itu berkaitan dengan objek individual. Ketiga, ketika saya menyebut tanda sebagai suatu simbol, kurang lebih hal itu diinterpretasikan sebagai objek denotatif lantaran adanya kebiasaan. Peirce dalam (Sebeok 1979). Saussure mengemukakan ada 3 teori dasar yaitu : Bahasa sebagai fakta sosial, bahasa sebagai sistem tanda, dan tipologi bahasa: language dan parole. Saussure juga mengemukakan bahwa ada 3 teori tanda yaitu :

a. Elemen tanda (sign) : signified signifier. 
Saussure memandang bahwa tanda bahasa memiliki dua fungsi, yaitu signified dan signifier yang merupakan kesan bunyi yang dapat didengar dalam khayal dan bukan ujaran yang diucapkan. Citra akustis dapat dilambangkan dengan alphabet $\mathrm{A}-\mathrm{Z}$ yang artinya citra akustis tidak lebih dari keseluruhan unsur atau fonem yang jumlahnya terbatas dan dapat diwujudkan dengan lambang yang tertulis dan bersifat sepadan (Taufiq, 2016)

b. Metode analisis: sintagmatikparadigmatik

Sintagmatik dan paradigmatik merupakan teori yang menganalisis metode tanda dan menjelaskan cara kerja tanda. Menurut Hoed kedua konsep tersebut terkait relasi atau hubungan antar komponen tanda dalam suatu system. (Hoed, 2011)

c. Pendekatan: sinkronis-diakronis

Saussure mengemukakan bahwa pendekatan sinkronis adalah suatu gejala kebahasaan yakni pada lapisan waktu dan ruang tertentu. Sedangkan secara diakronis dengan melihat perkembangan dari satu lapisan waktu ke lapisan waktu yang lain (Hoed, 2011)

Berbeda dengan Saussure, Peirce memiliki asumsi teori dasar yaitu :

1. Tanda sesuatu yang mewakili sesuatu yang lain bagi seseorang.

2. Tanda memiliki tiga dimensi yang saling terkait yaitu, Representamen (R) bentuk yang diterima oleh tanda atau berfungsi sebagai tanda, Objek (O) suatu yang diwakili oleh penanda yang berkaitan dengan acuan dan Interpretant (I) tanda yang ada di benak seseorang tentang objek yang dirujuk sebuah tanda.

Ketiga dimensi tersebut ketika dihubungkan satu sama lain menjadi segitiga yang biasa disebut dengan segitiga tanda (triadik, Christomy 2004).

\section{Interpretan ---- Objek ----- Representamen}

Peirce mengacu model tandanya sebagai model yang terdiri atas tiga hubungan yaitu interpretant, represantemen dan objek (tanda, suatu yang dilambangkan, kognisi yang dihasilkan dalam pikiran) (Noth, 2006)

Dalam analisis semiotiknya, Peirce mengemukakan ada beberapa konsep terkait tanda yang dihubungkan dengan logika, yaitu segitiga tanda antara ground, interpretant dan objek.

1. Ground merupakan suatu yang membuat tanda dapat berfungsi (dasar atau latar dari tanda. Dalam ground terdapat konsep mengenai qualisigns (Tanda yang menjadi tanda berdasarkan sifatnya), sinsigns (Tanda yang menjadi tanda berdasarkan bentuk atau rupa dalam kenyataannya) dan legisigns (Tanda yang menjadi tanda berdasarkan suatu peraturan yang berlaku umum)

2. Objek unsur kenyataan tanda. Tanda diklasifikasikan menjadi ikon, indeks, symbol.

\section{A. Ikon}

Ikon merupakan tanda yang memiliki kemiripan rupa dengan objeknya. sedangkan Peirce memberikan definisi ikon pada kriteria yang berbeda dan valid untuk sekumpulan fenomena semiotik. Salah satu kriteria utamanya didasarkan pada kategori semiotik kepertamaan firstness-nya. Kriteria lainnya adalah kesamaan antara alat tanda dan objeknya. (Noth. 2006.)

\section{B. Indeks}

Peirce mendefinisikan indeks sebagai tanda yang mewakili sesuatu berdasarkan keterkaitan dan tidak hanya terdiri atas tanda alami, namun juga tanda konvensional. Ciri-ciri indeks menurut peirce adalah memusatkan perhatian interpreter pada objek, melibatkan keberadaan objek sebagai entitas individu, dan tidak menyatakan apa-apa namun memperlihatkan objek tersebut. (Noth, 2006).

\section{Simbol}

Peirce mengemukakan bahwa simbol merupakan tanda yang konvensional (melalui kesepakatan) atau persetujuan dalam konteks spesifik (Noth, 2006). Makna dalam simbol disepakati berdasarkan kesepakatan sosial ataukah melalui tradisi historis (Danesi 2004)

Peirce mengemukakan simbol dapat dikategorikan menjadi tiga yaitu : Simbol sebagai tanda konvensional, simbol sebagai tanda konotasi dan simbol sebagai tanda ikonis. Simbol sebagai tanda konvensional dikemukakan oleh peirce sebagai tanda konvensional yang arbitrer, simbol 


\section{4 | JURNAL ILMU BUDAYA}

Volume 8, Nomor 2, Tahun 2020 berlawanan dengan berbagai jenis tanda non konvensional, artinya simbol sebagai tanda yang subtitutif dan menurut penggunaan terminologis merupakan suatu golongan tanda arbitrer. (Noth 2006, 116) Simbol sebagai tanda ikonis dikemukakan oleh hegel dan Saussure (dalam Noth:2006) sebagai tanda yang dilahirkan (motivated sign) dengan mempertentangkannya dengan tanda yang arbitrer. Simbol sebagai tanda konotatif. Konstotasional simbolisme menandai simbol yang berbeda dengan arti yang berlebihan. (Noth 2006, 117-118)

3. Interpretant

Suatu tanda yang mengarah terhadap kenyataan yang ada dalam fikiran seseorang serta terciptalah suatu tanda yang setara. Dalam interpretant terdapat konsep berupa rheme, decisgn, dan argument. Rheme (Tanda yang ditafsirkan dalam pemaknaan yang berbeda-beda). Decigns (Tanda yang sesuai dengan fakta dan kenyataannya). Argument (Tanda yang berisi alasan tentang suatu hal). (Noth, 2006).

\section{HASIL DAN PEMBAHASAN}

Gambar karikatur yang didapat dari media daring dikelompokkan ke dalam tiga (3) bagian.

\section{Respons Pemerintah terhadap Pandemi}

Di Perancis kekuasaan penyelenggaraan pemerintahan dalam negeri seharihari berada di tangan Perdana Menteri sebagai pengejawantahan pemerintahan parlementer, sementara Presiden yang dipilih oleh rakyat sekali dalam lima tahun (quinquenat) banyak mengurusi hubungan luar negeri, keamanan darurat negara sebagaimana diamanatkan UUD negara Perancis. Oleh karena pandemi Covid 19 mengancam keamanan negara, maka yang bertanggung jawab sepenuhnya secara langsung adalah Presiden Republik, walaupun setiap pekan pada hari Rabu ada pertemuan di antara Presiden dan Perdana Menteri di Elysée, istana Presiden untuk membicarakan pelaksanaan kebijakan negara, khususnya yang dilaksanakan oleh
Perdana Menteri, semacam laporan mingguan kubu Matignon, kantor Perdana Menteri kepada Presiden. Dengan demikian dapat dipahami Presiden dibandingkan Perdana Menteri lebih banyak tampil ke publik dalam kaitan dengan persoalan pandemi Covid 19.

Pemerintah Perancis merespons pandemi Virus Corona dengan berbagai kebijakan yang dapat direpresentasikan melalui gambar-gambar karikatur berikut. Presiden Immanuel Macron memberlakukan kebijakan lockdown (le confinement) di seluruh wilayah Perancis. Presiden Macron berkata: lockdown membuat rakyat lebih terjamin (confines, faites lui confiance), saya menjamin kalian akan bekerja kembali (je saurai vous remettre au travail).

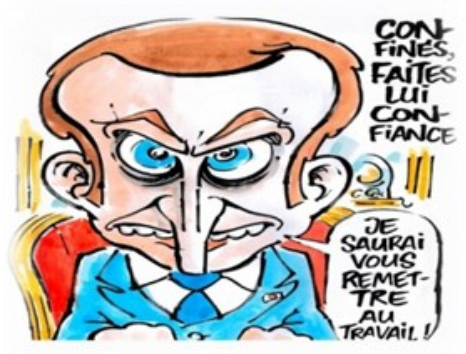

Gambar 1.

Kepastian pernyataan Presiden segera diikuti oleh tindakan menterimenteri. Menteri kesehatan yang mencalonkan diri menjadi Walikota Paris tahun ini, yang merupakan andalan Perdana Menteri untuk jabatan walikota tersebut, Agnès Buzin berucap: Perancis...Saya mengulurkan tangan untuk kalian semua (acceptez ma main tendue) artinya saya siap membantu semaksimal mungkin sesuai tugas dan bidang saya yang kebetulan pertama-tama terkait dengan bencana tersebut. Pernyataan tersebut menyiratkan besarnya tanggung jawab yang ingin diembang oleh perempuan karir tersebut.

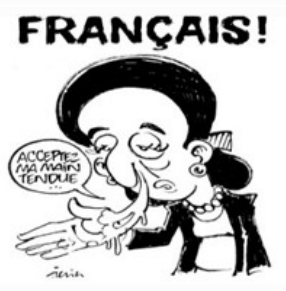

Gambar 2 
Polisi negara dengan sigap pula segera melaksanakan keinginan politik pemerintahan tersebut, seia sekata bahu membahu untuk memberikan perlindungan kepada warga. Pada masa virus corona merebak, polisi negara dan petugas keamanan lainnya terlibat langsung memperingati warga, sebagaimana tergambar pada karikatur berikut ini: éternuez dans vos coudes, sinon ....tutup mulut anda menggunakan siku bagian dalam saat bersin, jika tidak...! sambil polisi memiting leher seseorang.

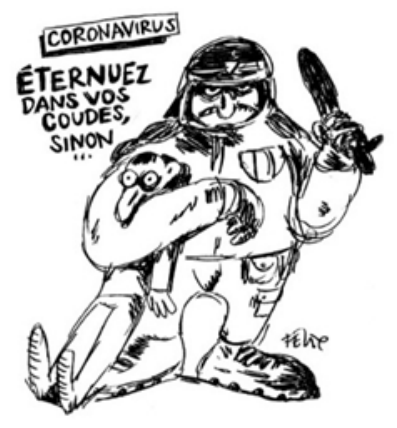

Gambar 3.

Sebagai Menteri Kesehatan yang terkait langsung dengan pandemi Agnes Buzin digambarkan dengan rambut yang berguguran, nyaris botak, untuk menggambarkan ketuaan di masa lalu, sambil mengatakan: untuk melawan virus corona (guerre contre le coronavirus)... kita kembali pada pelajaran masa lalu (retenons les leçons du passé).

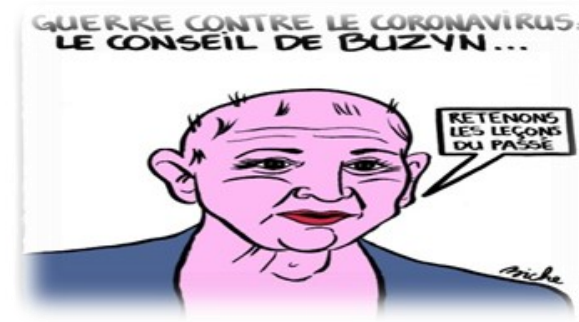

Gambar 4.

Masa lalu yang bagaimana? Jawaban atas pertanyaan tersebut dijelaskan oleh Presiden Macron sebagai masa lalu perancis yang memiliki kebudayaan yang jaya, disegani dan abadi dalam hampir semua aspek peradaban.

Perancis pernah memiliki kaisar Napoleon yang kekuasaaanya membentang dari Samudra Atlantik hingga Mesir di Timur Tengah. Mereka memiliki Bahasa yang hampir seluruh kerajaan-kerajaan besar di Eropa menggunakanya sebagai lambang kehormatan dan kemegahan. Mereka bersama Italia adalah bagian dari provokator renaissance dalam bidang seni dan arsitektur. Pernah menjadi pusat Kristen Eropa yang menyaingi vatikan. Pemikir-pemikirnya pernah menjadi icon dunia pada saat peradaban Islam menurun pengaruhnya, seperti René Descartes dengan prinsip-prinsip rasionalisme. August Comte yang mendasari berdirinya ilmu pengetahuan (science) positif. Mereka juga pelopor dalam menolak kesewenangan rezim raja di raja dan pusat pertumbuhan kekuasan rakyat (demokrasi).

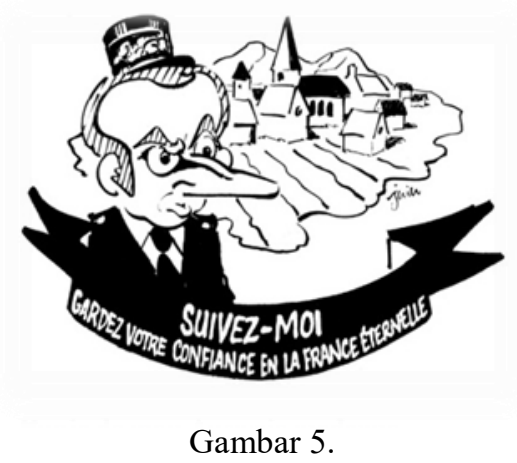

"Suivez-moi: ikuti saya" kata Macron. Tetaplah yakin pada legacy Perancis masa lalu yang abadi (gardez votre confiance en la France éternelle). Presiden dan jajaran menteri memilih cara tersendiri dalam membangkitkan energi dan memelihara keyakinan rakyat untuk tidak patah semangat dalam melawan pandemi. Namun begitu, kritik dan sindiran kepada kebijakan Presiden tetap saja ada.

Tatkala Macron menyerukan pentingnya solidaritas warga negara dan menyatukan hati dalam penderitaan bersama akibat pandemik Covid-19. Kata satukan hati diplesetkan seperti jatuh cinta dalam asmara. Kutipan berikut berkata: Satukan hati dalam penderitaan....biarkan kami bekerja Tuan Macron (Unis au Coeur de l'épreuve), perawat menegur (laissezmoi travailler M. Macron). Terlihat gambar Macron -dengan simbol hati tanda cinta asmara- menempel di punggung perawat yang berseru ....biarkan kami bekerja Tuan Macron. 
Pemerintahan Presiden Macron tampaknya, atau tepatnya pihak oposisi di partai politik-meskipun tergabung dalam pemerintahan, senantiasa mencoba untuk terus menerus mengganggu upaya-upaya Macron dalam menangani pandemi Covid 19, sebabnya dapat ditebak, yaitu jika Macron berhasil membawa keluar Perancis dari krisis multidimensi tersebut, maka itu akan memudahkan Macron mendapat tiket dari rakyat untuk menduduki kursi kepresidenan untuk kedua kalinya, walaupun pemilihan sela, yaitu Perdana Menteri dan beberapa Walikota akan berlangsung pada tahun 2020 ini, tapi hal tersebut tidak membawa pengaruh apa-apa terhadap Presiden. Dengan menyadari gangguan tersebut, Presiden Macron dengan cerdas lalu menyerukan pentingnya persatuan setiap warga negara dalam menanggulangi secara bersama-sama pandemi tersebut. Presiden membakar semangat warga negara dengan slogan-slogan kebanggaan dan kharismatik yang merupakan milik Perancis di masa silam, bahwa mereka pernah memiliki Napoleon Bonaparte, Jeanne D'arch, Jules Ferry dan seterusnya.

Jabatan Menteri pada perombakan kabinet yang berlangsung bulan Juli diisi oleh partai-partai koalisi. Terbukti pada penyusunan kabinet terakhir, muka-muka lama yang berafiliasi pada Presiden Sarcoky, sekutu Macron kembali menduduki jabatan. Kursi jabatan Menteri Dalam Negeri, jabatan krusial dengan merebaknya rasialisme anti kulit hitam atau anti kulit puiti (Black Live Matters) diduduki oleh Gerald Darmanin, tokoh muda yang merupakan orang-orang Sarkozy. Bahkan, Perdana Menteri yang baru pengganti Edward yaitu Jean Castex adalah sekretaris pribadi mantan Presiden Sarkozy.

Pada karikatur lain, pemerintahan di bawah kepemimpinan Perdana Menteri lama Edward Phillipe menjadwal ulang program-program yang telah dicanangkan sekiranya tidak terkait dengan program dan bantuan kemanusiaan. (Cancel plans not humanity), misalnya pada karikatur berikut:

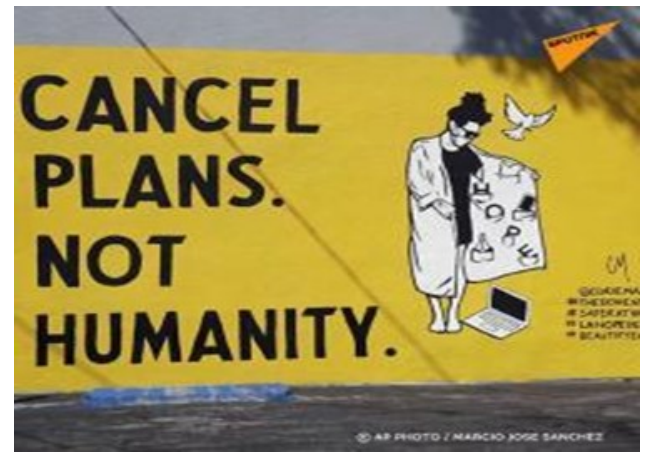

Gambar 7

Gonjang-ganjing politik dapat saja terjadi dan memanas, tetapi rencana dan program strategis untuk menyelamatkan warga negara dan rakyat adalah tujuan berdirinya negara, sehingga kepentingan rakyat banyak harus berdiri di atas kepentingan pribadi. Sistem politik yang kredible, transparan dan warga negara yang kritis dan demokratis menjadikan rencana penyelamatan hidup dan kehidupan lebih efektif. Program jangka panjang dan jangka menengah tetap dilaksanakan. Pengumuman, penyampaian dan himbauan berlangsung di mana-mana.

Penggunaan hand sanitizer dan alat pencuci tangan lainya diibaratkan seperti tank tentara yang disiapkan untuk melawan virus. Persenjataan yang akan menolong kita, l'armée va nous sauver.

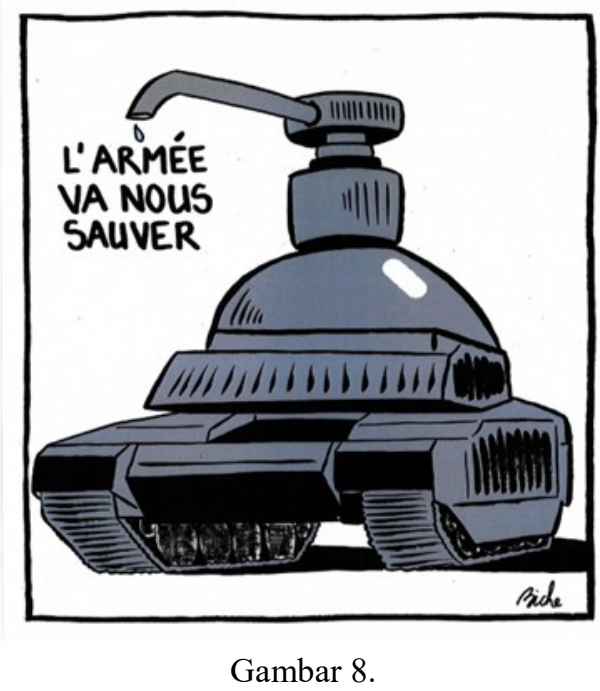

Menteri Pendidikan Nasional Jean Michel Blanquer turut disindir oleh Charli Hebdo. Dia merencanakan pembukaan sekolah pada tanggal 11 Mei 2020 bagi peserta didik yang selama ini diwajibkan belajar dari rumah. Namun, tenggat waktu 
yang diberikan untuk pembukaan sekolah dirasakan begitu cepat oleh masyarakat, sehingga menteri dianggap tidak peduli pada angka pandemi yang masih tinggi. Namun, monsieur Blanquer menyakinkan masyarakat, terutama orang tua siswa untuk tenang sebab pemerintah memperhatikan keselamatan mereka. Kata Menteri Blanquer, wahai para orang tua, yakinlah kalian: tidak seorangpun anakanak kita dibiarkan berada di pinggir jalan, (parents, rassurez-vous: aucun enfant ne sera laissé au bord du chemin).

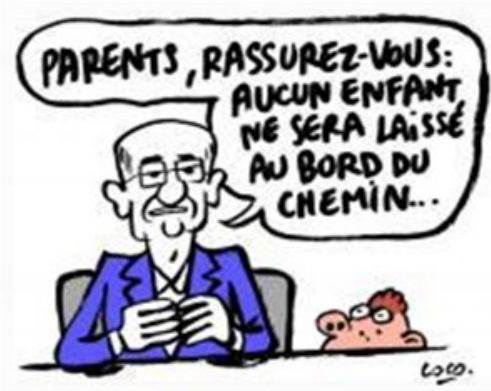

Gambar 9.

Pemerintah juga menghimbau agar masyarakat tidak egois dan menyelamatkan diri sendiri dengan jalan menimbun bahan makanan atau panic buying. Sindiran atas perilaku sebagian masyarakat yang mengambil keuntungan di balik pandemi, juga disindir di sini. Diperlihatkan seseorang yang justru tertimbun oleh bahan makanan yang dibelinya dari supermaket melewati keperluannya. Keranjang belanjaan jatuh terbalik dan menindihnya bersama barang belanjaan lainnya, seperti beras (rice) $50 \mathrm{~kg}$, gandum (la farine) 30 $\mathrm{kg}$. Di atas gambar tertulis korban berantai dari corona virus (victime collatérale $d u$ coronavirus).

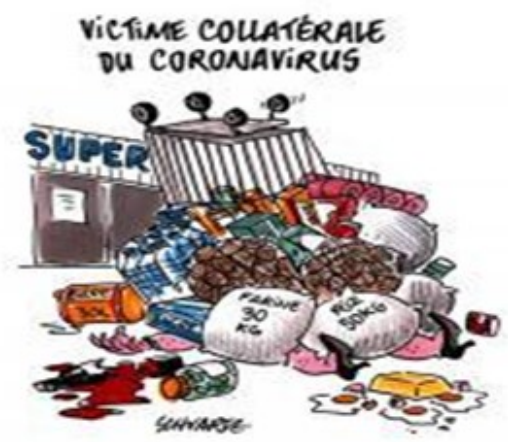

Gambar 10

\section{B. Tanggapan Masyarakat}

\section{Tanggapan Agamawan}

Coronavirus lebih kuat dari pada Tuhan (le coronavirus plus fort que Dieu). Untuk mengatasi ini, mari kita bersama mendirikan sekte baru (Tous avec moi pour fonder une nouvelle secte). Ini sindiran bagi peran agama-agama di Eropa yang tidak berfungsi lagi dalam menanggulangi wabah Corona. Sudah sejak sekularisme muncul, peran agama mulai ditingalkan, dan mereka mencari sumber-sumber keimanan baru.

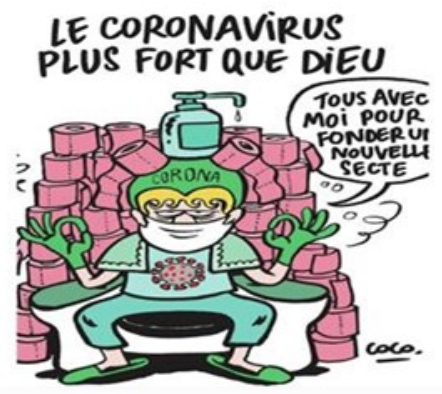

Gambar 11.

Karikatur berikut menggambarkan misa suci di gereja Saint-Nicolas $d u$ chardonnet, Sabtu 7 Maret 2020, pukul 10.00, sebagaimana tertulis di sebelah kanan atas gambar. Di bagian dalam gereja ini ditampilkan ornament kemewahannya, seperti jendela besar kaca tinggi yang dilengkapi seni kaca bakar (vitraux). Di bagian kiri atas tertulis, satu-satunya obat coronavirus adalah do'a (un seul remede: la prière).

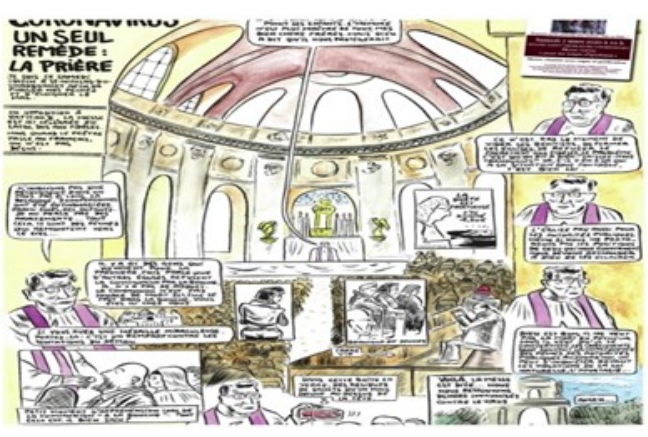

Gambar 12.

Khutbah dan do'a Bapak Pendeta ditulis di sekeliling, misalnya gereja mendo'akan juga para pejabat publik, walaupun kita tidak sependapat dengan mereka. Kita harus meminta agar Tuhan dapat menerangi mereka (l'église prie aussi 


\section{8 | JURNAL ILMU BUDAYA}

Volume 8, Nomor 2, Tahun 2020

Tertulis juga, di gereja ini ada beberapa jamaah yang baru pertama kali ikut, sebab gereja lain menolak perjamuan secara langsung. Padahal, tidak ada resiko. Perjamuan dengan mulut bukan penyebab kematian. Di sini semuanya dilakukan seperti biasa. Kalian seperti ada di rumah sendiri, (il y a ici des gents qui viennent pour la première fois parce que d'autres églises repusent la communion par la bouche. Il n'y a pas de risques. La communion n'est pas source de mort. Ici elle se fait dans la bouche. Vous êtes ici chez vous.

Bukan saatnya mengosongkan air suci, menutup gereja-gereja dan menolak pengakuan dosa. Masalahnya adalah Ketika orang berujar kepada Tuhan: "biarkan kami..damai atau ada diantaranya di bawah kontrol...Tuhan sangat baik: ce n'est pas le moment de vider les benitiers, des fermer les églises, de refuser le sacrament aux fideles. Le problème, c'est qu'on dit au Dieu: "Laissez nous tranquilles" or il y en a un qui a la situation sous controle. C'est Bien..lui.

Namun, kebalikan dari karikatur yang sebelumnya tentang ketidakmampuan agama dalam memberi solusi sosial dan virus ternyata lebih kuat dari pada Tuhan. Karikatur yang satu ini justru membuktikan kehadiran Tuhan yaitu Habermus Coronavirus.... Tuhan membuktikan kehadirannya sekarang. (A Dieu de prouver son existence maintenant).

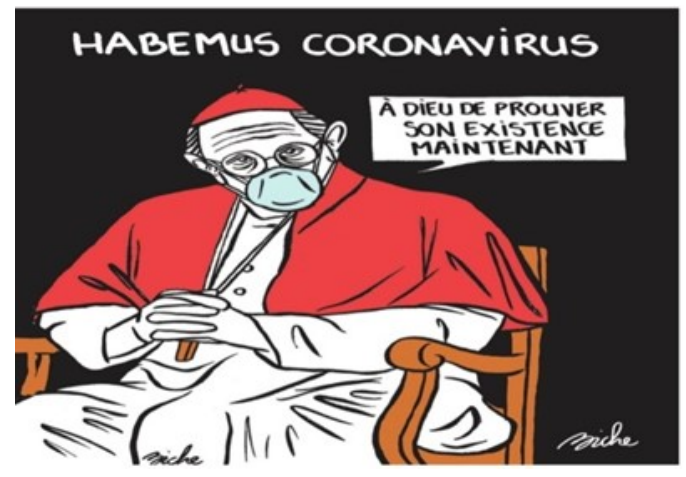

Gambar 13.

Demikian pula karikatur di bawah ini, sekali lagi membuktikan fungsi Tuhan.

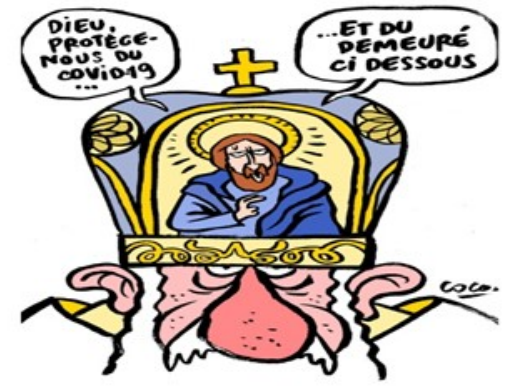

Gambar 14.

Tuhan melindungi kita dari Covid-19: Dieu, protégé-nous du covid-19.

Karikatur berikut ini, secara jelas disampaikan fungsi agama lewat orang yang mengaku sebagai anak Tuhan sebagai penyembuh. Selamat pagi, saya anak Tuhan (bonjour, je suis le fils de Dieu). Anak Tuhan adalah Jesus dalam agama Kristen, sebagai agama yang dominan di Barat, tetapi yang datang tersebut memakai baju dan membawa tas dokter. Lalu dijawab: "kami menunggumu...masuklah. (on vous attends, entrez).

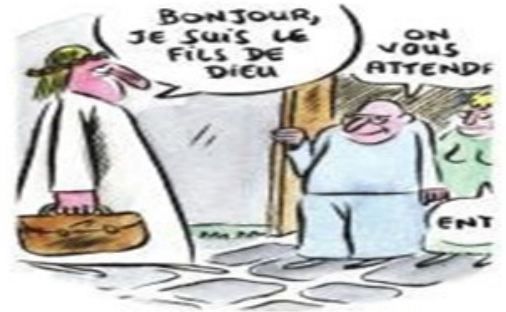

Gambar 15.

\section{Tanggapan Profesional}

Pertanyaan mengenai obat apa yang paling tepat untuk mengobati Covid-19 sempat menjadi perdebatan hangat di Perancis, bahkan di seluruh dunia, sebab ilmu pengetahuan seolah gagal, paling tidak untuk sekarang ini. Khusus di Perancis, hal ini dipicu oleh pendapat Prof Didier Raoult, Institut Medis di Marselli yang mengatakan obat chloroquine dan l'hydroxychloroquine dapat mengobati Covid-19. Namun, pendapat itu ditentang oleh penelitian lain setelah melakukan uji klinis pada beberapa pasien.

Au-delà de cette conclusion sur l'inutilité de la molécule pour la survie, le traitement par l'hydroxychloroquine aurait provoqué d'importants problèmes respiratoires et cardiaques: $27,4 \%$ des 


\section{9 | JURNAL ILMU BUDAYA}

Volume 8, Nomor 2, Tahun 2020 patients ont développé des syndromes de détresse respiratoire aiguë dans les sept jours après la prise de celui-ci, alors que moins de malades du groupe non-HCQ (24,1\%) ont été touchés par ces complications. Huit personnes ont également arrêté de prendre de l'hydroxychloroquine en raison de troubles détectés sur leurs électrocardiogrammes. En outre, les médecins ont noté l'importance majeure de ces résultats obtenus qui "n'encouragent pas l'utilisation de l'hydroxychloroquine chez les patients atteints d'une pneumonie due au Sars-Cov-2», vue l'inefficacité du médicament. (Sputnik, fr Le 20 avril 2020 à 20h45).

Polemik dari obat medis tersebut digambarkan dalam karikatur seperti di bawah ini, di mana Prof. Didier Raoult bercakap-cakap dengan koleganya, sesama dokter. "Saran yang paling manjur adalah penggunaan obat chloroquine, dengan 5 volume air semakin mantap" (Le haut conseil de santé evolué sur la chloroquine. Avec 5 volumes d'eau ça passé).

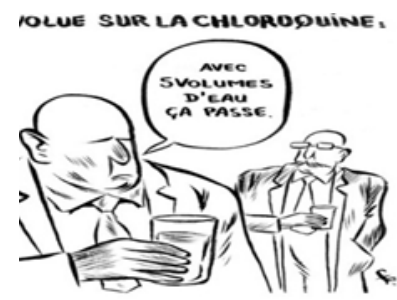

\section{Gambar 16

C. Optimisme dan Pesimisme
Masyarakat

\section{Optimism}

Bidang pariwisata adalah sektor yang ikut merasakan secara langsung dampak negatif dari pandemik Covid 19, padahal sektor pariwisata merupakan sektor andalan bagi Perancis dalam menyumbang income terhadap negara. Setiap tahun jutaan wisatawan manca negara datang berkunjung ke negara yang dianggap "paling romantis" di dunia untuk menyaksikan keindahan puri-puri, tamantaman yang indah, Menara Eiffel, Sacré Coeur dan terutama Monalisa, lukisan sangat terkenal dari Leonardo da Vinci.
Selama pandemi berlansung, tidak ditemukan lagi kerumuman orang-orang di taman-taman bunga yang penuh dengan bunga tulip berwarna warni, demikian pula taman-taman air mancur (fontaine) kosong dan tidak didapati orang duduk-duduk di sekeliling. Awal musim semi yang jatuh pada Bulan April pada saat pohon-pohon dan bunga bermekaran tidak dapat dinikmati lagi. Hari Musik yang menandai akhir musim dingin juga tidak dapat berlangsung. Monsieur dan madame menari di sepanjang jalanan, di Rue Mouftard, Arromdissement $\mathrm{V}$ tidak ditemukan lagi.

Namun gambar-gambar karikatur berikut membersitkan pengharapan dan optimisme yang tinggi terhadap pemulihan keadaan, bahwa semua kegembiraan di atas pasti akan tiba Kembali. Di saat Paris menjalani lockdown, sekumpulan lumbalumba tengah bermain asyik di sungai Seine yang tiba-tiba berwarna biru, sungai yang membelah kota. Padahal, selama ini begitu keruh dan padat ramai lalu-lalang bateaux bus mengangkut wisatawan menyusuri alairan sungai. Paris bernapas (Paris respire) menyatakan kondisi yang sedikit segar, cerah jauh dari hiruk pikuk kesibukan dan kepadatan aktivitas sebagai salah satu kota pusat mode dunia. Tampak sepasang burung pelican bercinta (la saison des amours), yang ironisnya diikuti pula oleh pasangan yang memakai masker mirip paruh burung pelican.

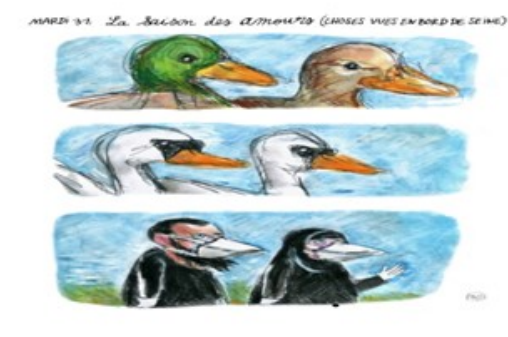

Gambar 17.

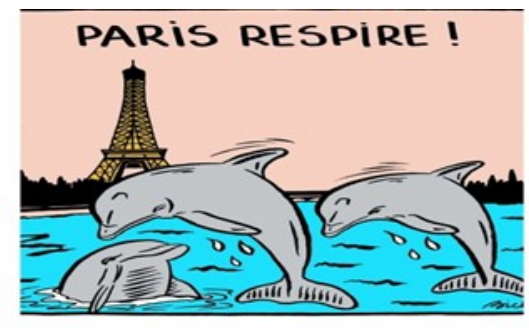

Gambar 18 
Walaupun dilanda pandemi Corona virus yang begitu dahsyat, Paris sebagai salah satu kota paling romantis di dunia tidak pernah bisa hilang pesonanya. Sepasang muda-mudi tetap memadu kasih, berciuman, walaupun digambarkan memakai masker. Pemandangan yang begitu lazim dilihat dalam kondisi-kondisi normal, sebagai salah satu identitas budaya masyarakat setempat.

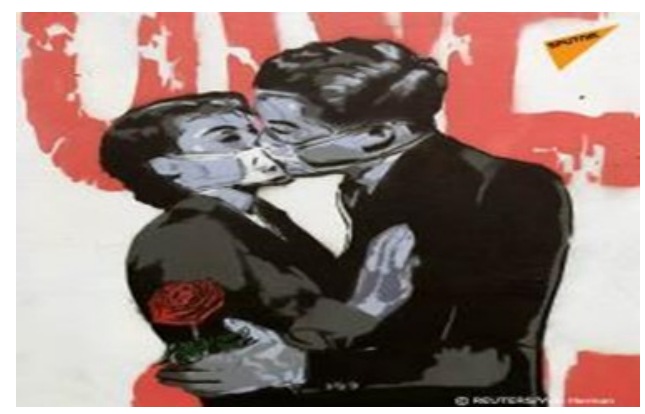

Gambar 19.

Di tengah gambaran pesimisme hidup, masyarakat Perancis tetap mengharapkan penderitaan kemanusiaan tersebut cepat berlalu dan aktivitas masyarakat, khususnya kegiatan di sektor ekonomi dan pedagangan pulih dan berdenyut kembali. Demikian pula, tenaga kerja dapat bangkit lagi. Ini terungkap lewat tulisan sebagai berikut: Hidup pertumbuhan (vive la croissance), di bagian atas. "Saya akan membagikannya secara gratis (je peux circuler librement)", kata laki-laki memakai rompi pekerja sambil mendorong bahan-bahan konstruksi suatu bangunan.

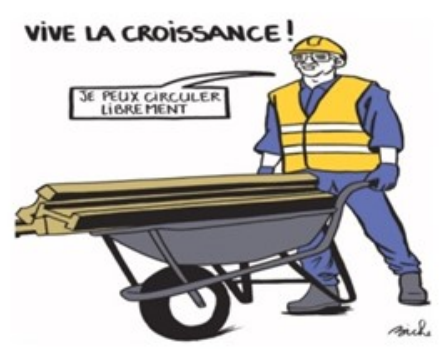

Gambar 20

\section{Pesimisme}

Di tengah pandemi, warga Perancis juga menyatakan bahwa pemerintah harus memberikan informasi yang benar dan valid kepada mereka mengenai covid-19.
Jangan ada rekayasa dalam pemberitaan. Itu digambarkan melalui karikatur berikut ini, yaitu seekor anjing merobek kiriman surat, (courier des lecteurs).

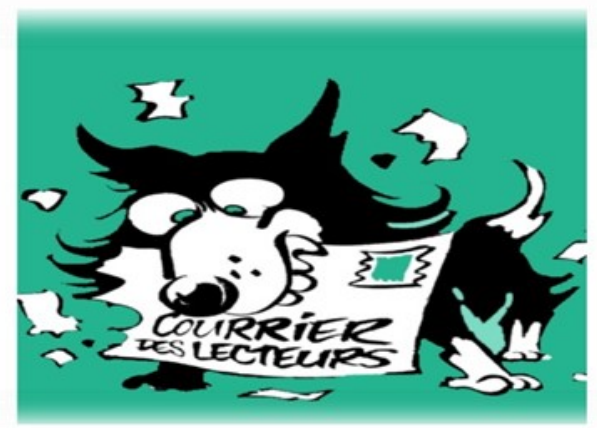

Gambar 21.

Bulan April adalah permulaan musim semi di Perancis, di mana bunga-bunga mulai bermekaran. Namun, tahun ini musim semi begitu kelabu, warga tidak dapat menikmatinya sebab pandemi virus corona. Situasi tersebut digambarkan melalui karikatur. Musim semi: pohonpohon sedang berbunga, Printemps: les arbres sont en fleurs.

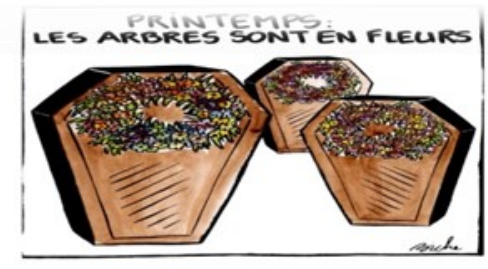

Gambar 22.

Dengan tingkat kematian yang tinggi kurang lebih 2751 orang membuat pekerja medis, baik dokter maupun perawat mulai kelelahan bekerja, sebab jumlah pasien yang banyak dilukiskan pula dalam karikatur. Terlihat seseorang dengan kalkukasi dan rencana opsi pengobatan (A,B,C,D), namun seorang juru medis terkapar di sampingnya, kelelahan dengan jarum suntik berujar, pembatasan dosis sudah mulai, (extinction a déjà commencé).

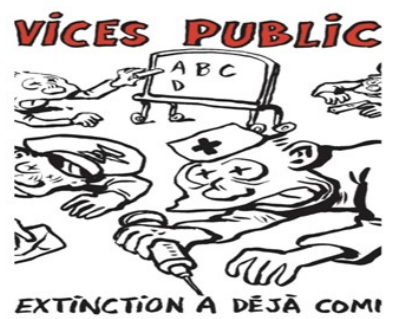

Gambar 23. 
Ramadhan tiba di tengah pandemi covid tidak lepas dari sindiran karikatur. Seorang muazzin terlihat mengumandangkan azan di atas menara sebuah masjid. Seekor burung yang hinggap di dekatnya berkata: Ah....muassin, anda kurang azan (Ah il la ramène moins, le muezzin).

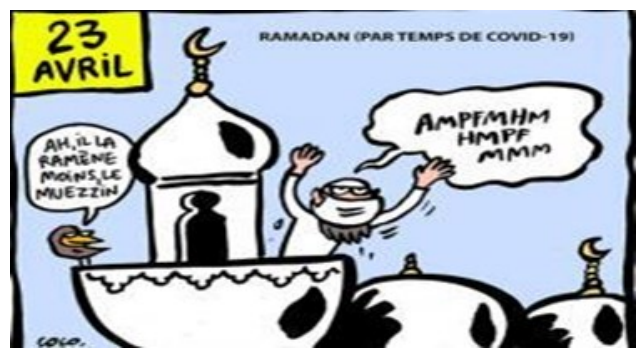

Gambar 24.

\section{Sindiran kepada Pemerintah Cina}

Pandemi Covid 19 yang mulai menyebar di Kota Hubei, Propinsi Wuhan melanda di hampir semua benua di dunia membuat negara-negara Barat dan Amerika memikirkan perlawanan terhadap Cina Komunis. Akibat yang ditimbulkan begitu dahsyat, dan bukan saja secara khusus di bidang kesehatan, tetapi menyentuh semua bidang kehidupan, seperti bidang politik sosial dan ekonomi. Negara-negara di dunia mulai merasakan dampaknya sekarang dan diprediksi akan berlanjut pada tahun 2021 mendatang. Krisis tersebut mulai resesi ekonomi, pengangguran yang tinggi, Pemutusan Hubungan Kerja (PHK), dan terutama korban meninggal yang terus bertambah jumlahnya, terutama pada negara-negara yang fasilitas kesehatan jauh dari memadai, termasuk Indonesia. Perusahanperusahan multinasional besar mengalami stagnan dalam pertumbuhan, sebab perputaran produksi dan penjualan yang tidak berjalan, malah menyentuh level minus.

Perang dagang antara Amerika dan Cina yang berlangsung jauh sebelum Covid 19 semakin mematangkan situasi. Gugat menggugat antara kedua pemerintahan semakin berlangsung panas. Amerika menuduh Cina harus membayar mahal dengan membuka penyelidikan yang objektif dan transparan terhadap tempat dan sumber virus di negaranya. Cina tidak kalah sengit membalas bahwa tentara Amerika yang membawa virus ke Wuhan, yang membawa virus ke Wuhan, yang kebetulan sesaat sebelum pandemi, tentara Amerika berkunjung ke Cina dalam rangka kerja sama militer. Kabar belakangan yang lebih mengagetkan bahwa Amerika di bawah pemerintahan Presiden Donald Trumps sudah memutukan bahwa paling tidak pada akhir tahun 2021 Amerika akan menghentikan donasi terhadap World Health Organisation (WHO), bahkan jika perlu Amerika akan menarik diri dari keanggotaan Lembaga PBB yang bergerak di bidang Kesehatan tersebut. Amerika menuduh WHO terlalu memihak Cina dalam hal komunikasi data-data, opini dan pemberitaan terhadap Covid 19.

Karikatur berikutnya adalah Sebagaimana diketahui negara-negara Barat meminta keterbukan Cina atas sumber pandemi Covid tersebut. Beberapa asumsi sempat muncul tentang sumber virus dari mulai binatang kelelawar di pasar kota Wuhan, sebagai sumber virus hingga tuduhan bahwa virus tersebut buatan manusia di Pusat Penelitian Virus yang terletak beberapa mil dari pusat kota Wuhan.

Negara-negara Barat diwakili Inggris sempat mewacanakan untuk menyeret Cina pada Mahkamah Internasional, namun mungkin sulit dilakukan. Karikatur berikut menggambarkan seekor pinguin yang mencandang tas, bertuliskan Cina dan kalimat loin des préjugés (jauh dari tuduhan).

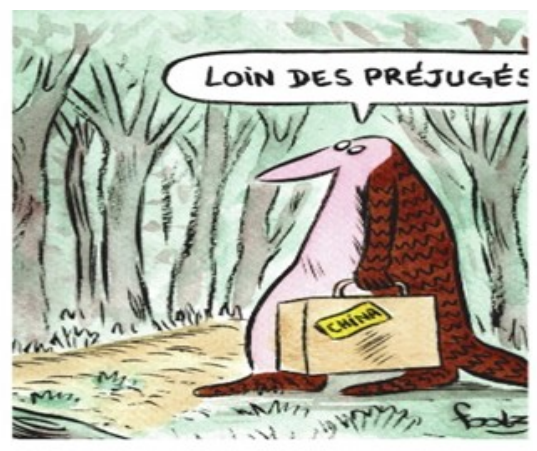

Gambar 25.

Dengan penuh satir, karikatur berikut memperlihatkan cara RRC menyelesaikan pandemi ini, yaitu dengan mengenakan masker tetapi dengan cara masker digulung terlebih dahulu untuk menyumbat mulut. 
Tertulis, bagaimana cara Pemerintahan Cina mengatasi corona virus (comment la chine maîtrise le corona virus). Kemudian disambung kalimat di bawah gambar, le silence, c'est la santé (diam adalah sehat). Suatu sindirian yang dialamatkan kepada rezim Cina yang tidak demokratis, di mana perbedaan pendapat, hak bersuara masih dianggap tabu.

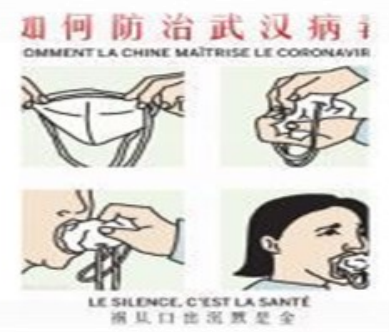

\section{Gambar 26.}

KESIMPULAN

Dari penelitian mengenai Semiotika Karikatur Pandemi Covid-19 Melalui Media Daring (on line) di Perancis dapat disimpulkan bahwa:

a. Pemerintah Perancis serius menangani pandemi Corona virus, terlihat dari keterlibatan Presiden dan jajaran Menterinya. Dalam membangkitkan semangar rakyat, Presiden mengingatkan kebesaran dan kehormatan bangsa di masa lalu. Aktivitas perempuan ikut mengantisipasi kemungkinan peningkatan KDRT selama lockdown (le confinement). Namun, upaya pemerintah tersebut tidak terlepas dari kritik warga, misalnya informasi dari pemerintah yang diharapakan lebih jujur dan tidak direkayasa.

b. Masyarakat umumnya merespons dengan baik peringatan pemerintah untuk tetap tinggal di rumah, ada rasa optimisme bencana akan berakhir, namun rasa frustrasi dan daya tahan warga terbatas. Bulan April adalah awal musim semi di Perancis dan Eropa pada umumnya, namun mereka tidak dapat menikmatinya seperti biasa, yaitu keluar ke taman-taman menyaksikan bungabunga yang beraneka ragam. Kalangan agamawan mengeluarkan pernyataan sesuai kompetensinya, begitu juga kalangan dosen berbicara sesuai bidang ilmunya. c. Kritik kepada RRC juga disampaikan melalui karikatur, apalagi negara tirai bambu tersebut menutup diri terhadap penyelidikan Internasional mengenai asal usul virus.

\section{DAFTAR PUSTAKA}

Abbas, Lutfi. Linguistik Bahasa Indonesia Cet.1. Bandung: Universitas Padjajaran, 1967.

Barthes, Roland. 1968. Elements of Semiology. New York: Hill and Wang Bauer, Laurie. Introducing Linguistics Morphology. Great Britain: Edinburgh University Press, 1988.

Berger, Arthur Asa. Semiotika : Tandatanda dalam Kebudayaan Kontemporer. Jakarta: Tiara Wacana, 2015.

Christomy. "Semiotika Budaya." In Semiotika Budaya, by Yuwono, 117. Depok: Pusat Penelitian Kemasyarakatan dan Budaya UI, 2004.

Danesi, Marcel. Pesan Tanda dan Makna. Yogyakarta: Jalasutra, 2004.

Hoed, Benny. Semiotik dan Dinamika Sosial Budaya. Depok: Fakultas Ilmu Budaya UI, 2011.

Mahsun. Metode Penelitian Bahasa: Tahapan Strategi, metode, dan tekniknya. Edisi Revisi Cet.8. Jakarta: Rajawali Press, 2014.

Matthews, P.H. Morphology: An Introduction to the Theory of World Structure. London: Cambridge University Press, 1974.

Moleong, Lexy. "Metodologi Penelitian Kualitatif." In Metodologi Penelitian Kualitatif, by Lexy Moleong, 103. Bandung: PT. Remaja Rosdakarya., 2002.

Noth, Winfried. Semiotik. Terjemahan oleh Dharmajo, Jumadi, Eti Setiawati, Aleda Mawene. Malang: Airlangga University Press, 2006.

Purnanto, Dwi. "Kajian Morfologi Derivasional dan Infleksional." Kajian Linguistik dan Sastra Vol.18, no 35, 2006: 136-152.

Rayya, Helfina. Telaah Konsep Semiotik 
Ferdinand de Saussure, Tth: 14.

Saussure, de Ferdinand. Course In General Linguistics. Paris: Payot, 1990.

Sebeok, Tomas. "Perfussion of Signs." "Perfussion of Signs" Vol. 55, No 1, 1979. Vol. 3, No 2 (Universitas Muhammadiyah Yogyakarta), 2014.

Sudaryanto. Metode dan Teknik Analisis Bahasa. Yogyakarta: Sanata Dharma University Press, 2018.

Supriadi, S., Maknun, T., Said, I.M. 2019. Karikatur Politik dalam Media Cetak Harian Rakyat Sulsel: Kajian Semiotik. Jurnal Ilmu Budaya, 7 (1), 134-145

Usman, Moses. Alat Penganalisis bahasaBahasa di Dunia Morfologi dan Sintaksis. makassar: Alauddin University Press, 2013.

Zoest, Aart Van. Semiotika: Tentang Tanda, Cara Kerjanya dan Apa yang Kita Lakukan dengannya. Jakarta: Yayasan Sumber Agung, 1993.

Sumber daring:

Charlie Hebdo

Le Monde

Sputnik. Fr 